\title{
Evaluation of acute radiation effects on mandibular movements of patients with head and neck cancer
}

\section{Avaliação dos efeitos agudos da radioterapia sobre os movimentos mandibulares de pacientes com câncer de cabeça e pescoço}

Karoline C. Bragante', Daniela M. Nascimento', Neiro W. Motta²

\begin{abstract}
Objectives: To evaluate radiotherapy effects (RT) on mandibular movements of patients with head and neck cancer (H\&NC) and associate them to the variables: functional capacity, radiation field, disease staging, type of feeding, concomitant chemotherapy and total dose of RT. Methods: Twenty-six patients with H\&NC were followed up at the RT service. Physical examination was performed in 3 follow up time points: before the beginning of RT (T0), between $14^{\text {th }}$ and $17^{\text {th }}$ session of RT (T1) and after the last session of RT (T2). The physical examination consisted of the assessment of the following variables: mouth opening without pain (MO), maximum mouth opening (MMO), right lateral excursion (RLE), left lateral excursion (LLE) and protrusion (PR) of the jaw. The feeding type and the Karnofsky Performance Status Scale (KPS) were evaluated in each follow up time point. Data with regards to the tumor lesion and the RT were collected from the patient's clinical notes. Results: There was a statistical significant reduction in the values of MO $(p=0.006)$, MMO $(p=0.001)$, LLE $(p=0.006)$ and KPS $(p=0.001)$. There was significant a statistical association among the reduction in KPS and decreased measure of $\mathrm{MO}(r=0.390, p=0.048)$ and $\mathrm{MMO}(r=0.435, p=0.026)$. The mouth and oropharynx radiation fields when combined showed a significant reduction for both the measure of $\mathrm{MO}(\mathrm{p}=0.005)$ and for $\mathrm{MMO}(\mathrm{p}=0.004)$. Patients who used nasoenteric tube feeding (NTF) had greater reduction in the measurement of MMO $(p=0.031)$. The remaining variables showed no statistically significant difference. Conclusion: Patients with H\&NC present reduction of the measures of MO and MMO during the RT, especially if they present reduced functional capacity, have radiation in the mouth and oropharynx fields and used NTF.
\end{abstract}

Keywords: radiotherapy; trismus; head and neck neoplasms; joint range of motion.

\section{Resumo}

Objetivos: Avaliar os efeitos da radioterapia (RT) sobre os movimentos mandibulares de pacientes com câncer de cabeça e pescoço (CCeP) e associá-los às variáveis: capacidade funcional, campo de radiação, estadiamento da doença, tipo de alimentação, quimioterapia concomitante e dose total de RT. Métodos: Vinte e seis pacientes com CCeP foram acompanhados em um serviço de RT. O exame físico ocorreu em três momentos: antes do início da RT (M0), entre a $14^{\circ}$ e $17^{\circ}$ sessão (M1) e após a última sessão de RT (M2) para verificação de variáveis, como: abertura bucal sem dor $(A B)$, abertura bucal máxima $(A B m)$, excursão lateral direita ( $E X d)$, excursão lateral esquerda ( $E X e)$ e protrusão (PR) da mandíbula. O tipo de alimentação e a Escala de Karnofsky (EK) foram reavaliados em cada momento. Dados a respeito da lesão tumoral e RT foram coletados do prontuário do paciente. Resultados: Houve redução significativa nos valores de $A B(p=0,006)$, $A B m(p=0,001)$, $\operatorname{EXe}(p=0,006)$ e $E K(p=0,001)$. Houve associação estatisticamente significativa entre a redução na $E K$ e a diminuição de $A B$ $(r=0,390 ; p=0,048)$ e de $A B m(r=0,435 ; p=0,026)$. Os campos de radiação da boca e orofaringe, quando agrupados, apresentaram redução significativa tanto para a medida de $A B(p=0,005)$ quanto para $A B m(p=0,004)$. Os pacientes que utilizaram sonda nasoentérica (SNE) apresentaram maior redução da medida de $A B m(p=0,031)$. As demais variáveis não apresentaram diferença estatisticamente significativa. Conclusão: Os pacientes com CCeP apresentam redução das medidas de AB e ABm no decorrer da RT, principalmente se apresentarem redução da capacidade funcional, tiverem irradiação para os campos da boca e orofaringe e fizerem uso de SNE.

Palavras-chave: radioterapia; trismo; neoplasias de cabeça e pescoço; amplitude de movimento articular.

Received: 07/15/2011 - Revised: 10/02/2011 - Accepted: 10/25/2011

${ }^{1}$ Physical Therapy Department, Methodist University, Instituto Porto Alegre (IPA), Porto Alegre, RS, Brazil

${ }^{2}$ Department of Radiotherapy, Santa Rita Hospital, Irmandade Santa Casa de Misericórdia de Porto Alegre (ISCMPA), Porto Alegre, RS, Brazil

Correspondence to: Karoline Camargo Bragante, Rua Coronel Corte Real, 827/402, CEP 90630-080, Porto Alegre, RS, Brasil, e-mail: karolb_fisio@hotmail.com 


\section{Introduction : :8.}

Head and neck cancer (H\&NC) presents a worldwide estimated incidence of 780.000 new cases per year ${ }^{1}$. In Brazil, the National Institute of Cancer (INCA) estimated that in 2010 10.330 new cases of cancer involving the head and neck areas among men and 3.790 among women occurred ${ }^{2}$. The anatomical sites that are included in this group of neoplasms are the oral cavity, which comprises oral mucosa, lips, gums, hard palate, tongue, mouth floor and retromolar trigone; pharynx, which includes oropharynx (base of tongue and soft palate), nasopharynx and hypopharynx (pyriform sinus, pharyngeal wall and post-cricoid area); nasal cavity and paranasal sinuses; glottis and supraglottic larynx; and salivary glands ${ }^{1,3}$. Approximately $40 \%$ of H\&NC occur in the oral cavity, $25 \%$ in the larynx, $15 \%$ in the pharynx, $7 \%$ in the salivary glands and $13 \%$ in other $\operatorname{areas}^{3,4}$. The most frequent histological type is the squamous cell carcinoma, present in more than $90 \%$ of cases $^{1,3,5}$.

Several factors are involved in the genesis of head and neck cancer, including genetic predisposition ${ }^{1,6}$; professional activity such as exposure to textile fibers, leather and nickel ${ }^{7}$; social conditions and habits, being the consumption of tobacco and alcohol the most significant risk factors ${ }^{1,3,8,9}$. Variables such as age over 40 years-old, male gender and white race may be also considered as predisposing factors for its development ${ }^{3}$.

Therapeutic modalities for the treatment of head and neck cancer include surgical, procedures, radiotherapy and chemotherapy, which may be used separately or in combination ${ }^{8-10}$. Radiotherapy (RT) is a modality used in the treatment of malignant tumors which the therapeutic agent is the ionizing radiation, i.e. that one which promotes ionization in the environment where charged, turning it electrically unstable ${ }^{11,12}$. By creating unstable atoms whose free electrons join to other adjacent atoms, which also become unstable with increased negative charges, damage to the cellular deoxyribonucleic acid (DNA) occurs, preventing the replication of the neoplastic cell ${ }^{13}$. The ionizing radiation treatment, however, is not selective, as it does not have the capacity to differentiate the normal cells from the malignant ones, which turns it toxic for the body ${ }^{13}$.

Adverse reactions due to RT depend on the volume and the area that will be irradiated, whether the exposure will be unilateral or bilateral, total dose, dose fractionation, age, patient clinical condition, social habits, such as alcoholism and smoking and the associated treatments ${ }^{12-15}$. Most of patients undergoing RT for head and neck receive a total dose from 50 to 70 Gray (Gy) as a curative dose. These doses are fractionated in a period from five to seven weeks, once a day, five days a week, with daily dose of approximately $2 \mathrm{~Gy}^{8,11,15}$.

The side effects of RT established for the treatment of patients with $\mathrm{H} \& \mathrm{NC}$ significantly interfere on the quality of life of these individuals ${ }^{16}$. Among the effects located in the head and neck area it may be mentioned: mucositis, dermatitis, dry mouth, hypogeusia, osteoradionecrosis, fibrosis and trismus ${ }^{4,11,13,15}$. Radiation-induced trismus, a reduced mobility of the jaw ${ }^{17,18}$ due to the fibrosis that occurs in the masticatory muscles when they are in the radiation field ${ }^{5,17-19}$ has a negative impact on the quality of life of the patients ${ }^{5,13}$, as it causes alterations in the facial appearance ${ }^{18}$, difficulty in food intake $e^{5,10,20}$, in the use of dental prostheses ${ }^{10}$ and in the speech ${ }^{5}$, compromises the oral hygiene $e^{5,19}$ and it may lead to depression ${ }^{5}$.

Some authors ${ }^{9,21}$ suggest that radiation-induced trismus may only be established months after the end of radiation therapy and if the patient underwent to high doses, while other authors $^{5,22}$ state that, during the course of radiation therapy may occur restriction of the mandibular movements even after low doses of irradiation. Several studies ${ }^{17,21-24}$ reported the relationship of trismus with specific anatomical structures in the radiation field. In addition, some authors ${ }^{17,25}$ confirm the direct influence of this therapy associated with chemotherapy in the emergence of this complication, while other authors ${ }^{5}$ disagree.

Due to the contradictory data in the scientific literature with regards to the appearance of radiation-induced trismus in the course of irradiation therapy and the high rate of patients with H\&NC undergoing high doses of RT in extensive radiation fields ${ }^{11}$, there is a need to better investigate the occurrence of possible changes in the mandibular mobility in irradiated patients, as well as which associated factors would be involved in the onset of these complications, so that after this investigation, data for prevention programs and/or reduction of such dysfunctions may be provided.

Therefore, the objectives of this study were to evaluate the effects of RT on the mandibular movements of patients with $\mathrm{H} \& \mathrm{NC}$ and, secondarily to investigate the association of these effects with the following variables: functional capacity, radiation field, disease staging, type of feeding, use of concomitant chemotherapy and total dose of RT.

\section{Methods : :}

\section{Study design and sample}

This is a prospective cohort study in which patients with H\&NC, assisted by the Unified Health System in the Radiotherapy Service of the Santa Rita Hospital (HSR) of the Irmandade Santa Casa de Misericórdia de Porto Alegre (ISCMPA), Porto Alegre, RS, Brazil, were evaluated and followed up. These patients started radiotherapy between February and May 2010. The sample size calculation was carried out based on the study 
of Grandi et al. ${ }^{26}$ for a significance level of $5 \%$, a power of $80 \%$ and an effect size of at least 0.6 among the evaluations, and it resulted a minimum number of 22 patients to contemplate the study design.

The assessment of eligibility for participation in the study followed the criteria: 1) inclusion criteria: Male and female over 18 years-old, with diagnosis of $\mathrm{H} \& \mathrm{NC}$ undergoing curative RT alone or in combination with chemotherapy, with one or more masticatory muscles on the radiation field and who had percentile higher than $40 \%$ in the Karnofsky Performance Status Scale (KPS) ${ }^{27}$. 2) exclusion criteria: individuals who had performed surgical intervention to remove the tumor in any of the mastication muscles, presenting facial palsy, trigeminal neuralgia or herpes zoster, patients in treatment with brachytherapy, patients who were receiving physical therapy, who have not performed any of the stages of the study and who refused to participate in the study.

Data from 32 patients were collected, being five patients lost to follow-up due to interruption of the radiotherapy as requested by the physician $(n=1)$ and for abandonment of the treatment with irradiation therapy in the above-mentioned institution $(n=4)$. One patient was excluded from the study for not being assessed in the last follow up. This study had a final sample of 26 patients. The data collection was concluded in July 2010.

\section{Data collection}

All patients who started the RT in HSR received information, in group, about the treatment by the nursing staff. In these groups, patients who met the inclusion criteria of the study were identified and the informed consent form was presented to them. After signing the consent form the data collection was initiate.

Each patient individually underwent to a brief initial interview and variables such as age, family history of cancer, smoking and alcoholic habits, as well as how long they have being smoking and/or drinking, classification by KPS scale, which is a scale of functional performance used in the prognosis of cancer therapy ${ }^{27}$, and type of feeding ${ }^{28,29}$ were collected. Data such as tumor location, histological type of tumor, tumor stage ${ }^{30}$, associated chemotherapy, radiation field and dose per session of RT were collected from the patient's chart for future correlations and characterization of sample.

The data collection from the physical examination aimed to assess the variables mouth opening without pain (MO), maximum mouth opening (MMO), right lateral excursion (RLE), left lateral excursion (LLE) and protrusion (PR) of the jaw followed the instructions and specifications of the clinical examination of the Protocol of Diagnostic Criteria of Temporomandibular
Disorders (RDC/TMD) ${ }^{31}$. The physical examination was always carried out by the same examiner, who was familiarized with this protocol, in three different time points: before the beginning of the RT, time 0 (T0); between $14^{\text {th }}$ and $17^{\text {th }}$ session, time 1 (T1) and immediately after the last session of the RT, time 2 (T2). Variables such as type of feeding and KPS scale were also evaluated at each time points.

All patients were treated with irradiation therapy by photons in parallel pairs or wedge angle with daily dose from 1.8 to 2 Gy until the end of treatment of approximately seven weeks. The total dose of the RT ranged from 50 to $70 \mathrm{~Gy}$.

The present study was approved by the Ethics in Research Committee of the Centro Universitário Metodista do Instituto de Porto Alegre (IPA) (Porto Alegre, RS, Brazil, number 393/2009), and by the Ethics in Research Committee of the ISCMPA, protocol 031/10.

\section{Statistical Analysis}

The collected data were stored in the Microsoft Excel 2003. To characterize the sample, the categorical variables of this study were described through absolute and relative frequencies; the continuous variables, through means and standard deviations for those that presented a normal distribution, and median and interquartile ranges in case of asymmetric distribution variables. The Shapiro-Wilk test was used to verify the normality of data. The comparison between physical examination variables in the three different time points was verified by the ANOVA for repeated measures followed by Bonferroni test or, when appropriate, by its correspondent non-parametric Friedman test followed by Wilcoxon test. The comparison among the physical examination variables and disease stage, type of feeding and radiation field was obtained by the oneway ANOVA test followed by Tukey test, and the variable chemotherapy was compared with the variables of physical examination by the Student $t$ test. Correlations were performed through Pearson correlation test. The statistical program used was SPSS, version 17.0. The significance level was set at $\alpha=0.05$ for all statistical analyses.

\section{Results $: \therefore$.}

In relation to the variable gender, all 26 (100\%) participants of this study were male. The volunteers' age ranged between 45 and 74 years old, with a mean age of 59.0 (SD=8.8) years. Regarding the distribution by race, there were 20 (76.9\%) Caucasians, five (19.2\%) Afrocaucasian and one (3.9\%) melanoderm. Regarding social habits, 26 (100\%) were smokers, with smoking mean time duration of $37.4(\mathrm{SD}=12.7)$ years, and $19(73.1 \%)$ 
participants reported regular intake of alcohol, with mean time duration of 29.5 ( $\mathrm{SD}=13.0)$ years. With regards to the family history of cancer, 13 (50\%) have reported family history of cancer and $13(50 \%)$ were not sure or had no cases of cancer in the family. Patients' distribution according to the tumor location, tumor histological type and tumor stage is shown in Table 1.

Regarding the comparison of the variables of the physical examinaton in the three different time points, there was a statistically significant reduction on the values of MO, MMO and LLE. There was also observed a statistically significant reduction in relation to KPS scale (Table 2).

There was a moderate positive statistically significant correlation among the reduction of the KPS scale and the decreased of MO ( $r=0.39 ; \mathrm{p}=0.048)$ and MMO measurements (Figure 1).

The analysis of the radiation fields shows that there was a tendency of the oropharynx and mouth fields present a greater reduction of mouth opening (Table 3). If oropharynx and mouth fields are combined and compared with the other radiation fields, it can be observed a statistically significant reduction in both, MO $(\mathrm{p}=0.005)$ and MMO $(\mathrm{p}=0.004)$ measurements. There were no statistically significant differences ( $\mathrm{p}>0.05$ ) among tumor staging and both $\mathrm{MO}$ and $\mathrm{MMO}$ measurements.

With regards to the type of feeding in $\mathrm{T} 0$ all patients reported oral food intake being the food in the normal consistency; in

Table 1. Patients distribution by tumor location, tumor histological type and tumor stage.

\begin{tabular}{lc}
\hline Variables & $\mathrm{n}(\%)$ \\
\hline Larynx & $12(46.2)$ \\
\hline Oropharynx & $10(38.9)$ \\
\hline Mouth & $8(30.8)$ \\
\hline Hypopharynx & $4(15.4)$ \\
\hline Nasopharynx & $1(3.8)$ \\
\hline Squamous cell carcinoma & $25(96.2)$ \\
\hline Undifferentiated Carcinoma & $1(3.8)$ \\
\hline Stage I & $1(3.8)$ \\
\hline Stage II & $4(15.4)$ \\
\hline Stage III & $5(19.2)$ \\
\hline Stage IVA & $12(46.2)$ \\
\hline Stage IVB & $4(15.4)$
\end{tabular}

Table 2. Comparison of the variables from the physical examination at three follow up times points.

\begin{tabular}{lllcc}
\hline Variables & \multicolumn{1}{c}{ T0 } & \multicolumn{1}{c}{ T1 } & T2 & $p$ \\
\hline MO & $36.7 \pm 10.4^{\mathrm{b}}$ & $34.2 \pm 11.4^{\mathrm{a}, \mathrm{b}}$ & $32.2 \pm 9.8^{\mathrm{a}}$ & $0.006^{\star}$ \\
\hline MM0 & $40.9 \pm 10.6^{\mathrm{b}}$ & $38.7 \pm 12.1^{\mathrm{b}}$ & $35.9 \pm 10.2^{\mathrm{a}}$ & $0.001^{\star}$ \\
\hline RLE & $8(5-10)$ & $8(4.8-10)$ & $5.5(3.8-8.5)$ & $0.133^{\star \star}$ \\
\hline LLE & $9(6.8-10)^{\mathrm{b}}$ & $8(5.0-10)^{\mathrm{a}}$ & $8(3-10)^{\mathrm{a}}$ & $0.006^{\star \star}$ \\
\hline PR & $5(2.8-8.3)$ & $4(2.0-5.0)$ & $4(2-6.3)$ & $0.154^{\star \star}$ \\
\hline KPS & $83.1 \pm 13.5^{\mathrm{b}}$ & $75.8 \pm 13.3^{\mathrm{a}}$ & $72.7 \pm 14.8^{\mathrm{a}}$ & $0.001^{\star}$ \\
\hline
\end{tabular}

The values of MO: Mouth opening; MMO: maximun mouth opening and KPS: Karnofsky Performance Status scale, are expressed in means and standard deviations. The values of RLE: right lateral excursion; LLE: left lateral excursion e PR: protrusion are expressed as medians and interquartile ranges *ANOVA for repeated measurements **Friedman test. a,b letters are not significantly different by the Bonferroni test or Wilcoxon $p<0.05$.
T1, seven (26.9\%) patients remained with normal feeding; 11 (42.3\%) reported eating only food in pasty consistency and eight (30.8\%) patients informed feeding exclusively for nasoenteric tube feeding (NTF). In T2, data about the type of feeding were the same as in $\mathrm{T} 1$.

Comparison between the variation of MO and MMO measurements according to the type of feeding showed values significantly lower of MMO measurement in patients who used NTF (Table 4).

Regarding the use of chemotherapy (cisplatin), 13 (50\%) participants had used it combined with the RT. When the patients who underwent chemotherapy are compared with those who did not realize this therapy there was no statistically significant difference ( $p>0.05)$ on the variation of $\mathrm{MO}$ and $\mathrm{MMO}$ measurements.

There was no statistically significant association between the total dose of radiation and the reduction of $\mathrm{MO}(\mathrm{r}=-0.111$; $\mathrm{p}=0.591)$ and $\mathrm{MMO}(\mathrm{r}=-0.164 ; \mathrm{p}=0.423)$ measurements.

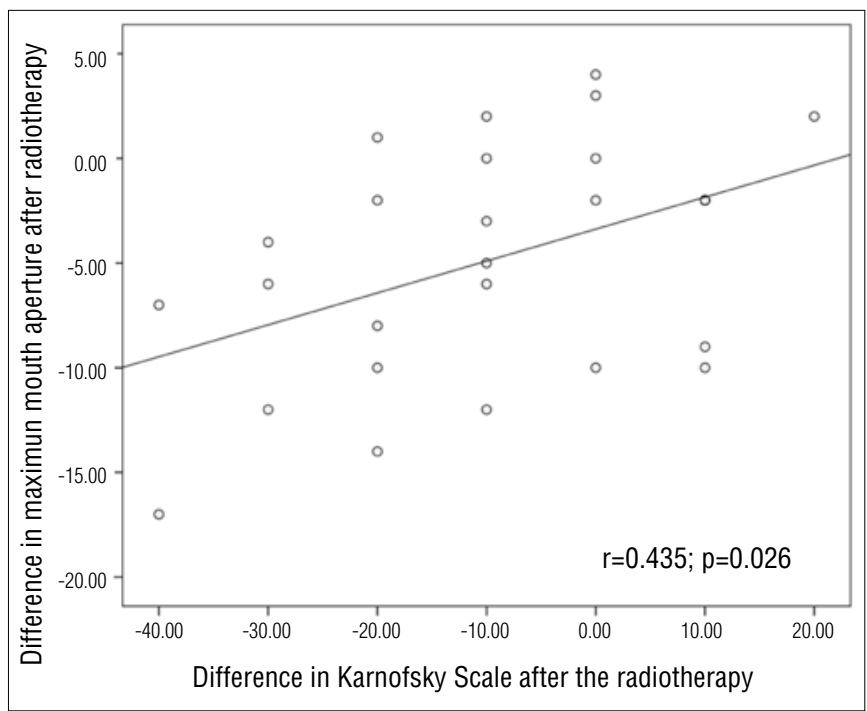

Figure 1. Pearson's correlation.

Table 3. Mouth opening variation according to the radiation field.

\begin{tabular}{lcccc}
\hline Variables & $\Delta \mathrm{M} 0=\mathrm{M} 0-\mathrm{M} 2$ & $p^{*}$ & $\Delta \mathrm{MM} 0=\mathrm{M} 0-\mathrm{M} 2$ & $p^{*}$ \\
\hline Oropharynx & $-13 \pm 4.2$ & & $-11.5 \pm 7.8$ & \\
\hline Larynx & $-5.2 \pm 7.4$ & 0.059 & $-5.3 \pm 6.3$ & 0.059 \\
\hline Hypopharynx & $0.0 \pm 0.0$ & & $-2.0 \pm 0.0$ & \\
\hline Mouth & $-10.0 \pm 4.7$ & & $-11.0 \pm 1.7$ & \\
\hline Drainage areas & $-2.1 \pm 5.2$ & & $-2.8 \pm 4.5$ & \\
\hline
\end{tabular}

The values of MO: Mouth Opening and MMO: Maximum Mouth Opening are expressed as means and standard deviations. *Anova one-way.

Table 4. Mouth opening variation according to the field of feeding.

\begin{tabular}{lcccc}
\hline Variables & $\Delta \mathrm{M} 0=\mathrm{M} 0-\mathrm{M} 2$ & $\mathrm{p}^{*}$ & $\Delta \mathrm{MM0}=\mathrm{M} 0-\mathrm{M} 2$ & $\mathrm{p}^{*}$ \\
\hline Normal & $-0.6 \pm 3.8$ & & $-0.6 \pm 3.6^{\mathrm{b}}$ & \\
\hline Pasty & $-4.2 \pm 5.8$ & 0.057 & $-5.6 \pm 5.0^{\mathrm{a}, \mathrm{b}}$ & 0.031 \\
\hline NTF & $-8.4 \pm 7.4$ & & $-7.9 \pm 6.2^{\mathrm{a}}$ & \\
\hline
\end{tabular}

The values of MO: Mouth Opening e MMO: Maximun Mouth Opening are expressed as means and standard deviations. *Anova one-way. a,b: same letters do not differ by the Tukey test $(p<0.05)$. 


\section{Discussion $\because:$.}

In relation to gender, age and race, the present results support the results existent in the literature, which showed a higher incidence of $\mathrm{H} \& \mathrm{NC}$ in males ${ }^{3,7-9,12,32}$, with predominance of individuals between the $6^{\text {th }}$ and $7^{\text {th }}$ decade of life $e^{3,4,8,9,33}$ and Caucasian $^{3,12,26}$.

Regarding the social habits all participants of this study declared themselves smokers and $73.1 \%$ and consumed alcohol, which strengthens the association between the intake of alcohol and tobacco for the development of $\mathrm{H} \& \mathrm{NC}^{3,7,9,34}$. Half of sample of the present study reported to have family history of cancer indicating that genetic predisposition may also be a risk factor for $\mathrm{H} \& \mathrm{NC}$ as shown in recent studies ${ }^{1,34-36}$.

The predominant histological type in this study was the squamous cell carcinoma, which is in agreement with the statistics of INCA ${ }^{2}$ and with other studies ${ }^{3,5,9,26}$. With regards to the anatomical site larynx tumor was the most prevalent in this study disagreeing with epidemiological studies that indicate predominance of cancers of the oral cavity ${ }^{3,4,34}$. Such disagreement may be explained due to the previous studies surgical patients were also included and in the present study patients with mouth cancer who require surgical procedures that embrace the masticatory muscles ${ }^{37}$ were excluded of the study. In relation to the patients' distribution by tumor staging, $46.2 \%$ presented IVA stage. The literature shows high incidence of advanced stage $H \& N C$ at the moment of the clinical diagnosis ${ }^{3}$.

Our results demonstrate that the RT significantly reduces the measure of MO and MMO over the course of the radiotherapy as reported in the study of Goldstein et al. ${ }^{22}$. Some authors, however, obtained different results, finding the presence of trismus only after nine weeks and six months of the end of the $\mathrm{RT}^{5,21}$. These discrepancies in the literature may be related with bias of retrospective data collections and with the variability in the evaluation form and definitions of trismus. Many authors ${ }^{21,38}$ have adopted as a measure of trismus a MO lower than $35 \mathrm{~mm}$, while other authors ${ }^{19,39}$ have adopted the measure of $40 \mathrm{~mm}$. Another study ${ }^{5}$ considered as criterion for trismus a MO lower than $35 \mathrm{~mm}$ in dentulous patients and a MO lower than $40 \mathrm{~mm}$ in edentulous patient. There is also no consensus on how to evaluate the mouth opening. It can be performed with a millimeter ruler, Will's compasses or calipers ${ }^{40}$.

The present study used a millimeter ruler for the measurements, as recommended by $\mathrm{RDC} / \mathrm{TMD}^{31}$ and had not established a cutoff point for trismus. We consider to be more accurate to evaluate the variation of measurement of the mandibular movements at different time points, thus if there were any restrictions of these movements already (inherent to the individual or due to the tumor) it was identified before the beginning of the RT allowing therefore, that only the alterations in consequence of the irradiation were analyzed. Many patient with head and neck cancer already present before the beginning of RT limited MO due to tumor invasion in the masticatory muscles or due to spasm reflex of these muscles ${ }^{18,21,41,42}$. This symptom tends to relieve or disappear during the course of the irradiation therapy, but it may reappear gradually in case of radiation-induced fibrosis in the masticatory muscles ${ }^{21}$.

The LLE measure showed statistically significant reduction. Due to the patients in this study had received radiation therapy in parallel pairs or in angled wedge, this reduction could be attributed to the unequal application of irradiation on parallel fields in patients who received bilateral radiation, as the uneven application on parallel opposed fields results in radiation-induced trismus on the side that received more irradiation according to the study of Wollin, Gilbert and $\mathrm{Kagan}^{43}$. Since in the present study the application method of the RT was not controlled and the radiation doses were not calculated for the specific muscle groups, it is not possible to affirm that such outcome is due to uneven application of radiation on parallel fields, being this difference occurring by chance. Prospective studies controlling the application of the RT on parallel fields should be carry out to determine whether the unequal application results in radiation-induced trismus on the side that have received more irradiation.

Technological advances in radiotherapy have been increasing the survival of patients with tumors ${ }^{15}$ demonstrating the importance of taking in consideration the impact of RT on functional and cosmetic aspects ${ }^{44}$. Our results demonstrated a significant reduction on the patients' functional status in the middle of the treatment, as have been reported in other study ${ }^{45}$. There was a positive correlation among the reduction in KPS scale and reduction of MO and MMO measurements, i.e. the patients that have presented a greater reduction the MO measurement were the ones who had the worst level of physical performance, which corroborate with the literature ${ }^{18}$. There is a need for a global physical rehabilitation in order to benefit the functionality of oncologic patients.

The region where the tumor is irradiated is known as radiation field. The core of the tumor receives the dose predetermined by the radiotherapist and the surrounding tissues receive lower doses of irradiation ${ }^{15}$. Our results showed that the radiation fields of oropharynx and mouth presented a greater reduction of the MO and MMO measurements. This occurs because in these fields the main jaw elevator muscles (masseter and medial pterygoid $)^{46}$ are in the path of the radiation beam receiving higher doses of radiation, which may lead to fibrosis of these muscles and generate radiation-induced trismus, corroborating with the literature $e^{5,17,19,22,42}$.

In the study of Johnson et al. ${ }^{18}$, patients who presented greater MO restriction were the patients with more advanced 
disease staging. This finding conflicts with the results of the present study, which demonstrate no statistically significant difference between the variation of the MO and MMO measurements and the tumor stages. According to some studies ${ }^{1,47}$, tumors that have the same clinical staging may demonstrate different patterns of evolution, suggesting that adverse reactions of RT require the analysis of other complementary factors.

According to some studies ${ }^{29,41,48,49}$ from 50 to $60 \%$ of patients with H\&NC have a relatively impaired feeding due to factors such as sore throat, dysphagia, xerostomy, ageusia, among others, and a significant involuntary weight loss becoming extremely necessary the enteral feeding tube. In this study, $30.8 \%$ of the patients fed through NTF since the middle of radiotherapy, and $42.3 \%$ had to change the consistency of food at the same period. Our results demonstrated that patients who fed trough NTF had greater MMO restriction compared to patients who remained feeding orally. The mandibular hypomobility caused by the use of NTF accelerates the degeneration of the muscles and the temporomandibular joint caused by $\mathrm{RT}^{50}$. Several studies have reported the use of chewing gum for the treatment of trismus ${ }^{19,26}$. Thus, it may be supposed that the chewing had a preventive function on the MO restriction in patients who remained feeding orally.

In the organ preservation therapy, chemotherapy combined with RT is frequently used nowadays ${ }^{17}$. In this study, half of patients had chemotherapy combined with RT. Researchers report that the combination of these treatments presents greater benefit for the tumor control, on the other hand, it increases the toxicity to the body resulting in excessive side effects ${ }^{17,29}$. In our results, however, chemotherapy combined with RT did not increase the incidence of $\mathrm{MO}$ and MMO restrictions, confirming the findings of Louise's Kent et al. 5 .

In the present results there was no association between total dose of RT and MO restriction. Individuals who received the same total dose of RT showed different MO pattern, corroborating with some studies ${ }^{51,52}$. Factors as radiation field, patient's functionality and type of feeding showed greater influence on the patient's MO compared to the total dose of radiation in the short-term evaluation of trismus.

Several studies ${ }^{24,42,53,54}$ have reported that the prevention of trismus instead of its treatment is the most desirable objective since the radiation-induced trismus is of difficult to recover. Therefore, early intervention of a physiotherapist, who is inserted in the multidisciplinary team working in the care of cancer patient, becomes extremely necessary to prevent or to reduce this frequent complication, with is occasionally ignored but with significant negative impact on the quality of life of patients with H\&NC. It is suggested that clinical trials to verify which physical therapeutic exercises would be more effective in the prevention of MO limitation should be carried out.

The main limitation of this study was that, when creating subgroups for analysis of the secondary objectives a type II error might have occurred due to the small sample size. Due to the small sample size, the anatomical subsites of the tumor lesion were not analyzed with regards to the MO restriction, which should be investigated in future researches. Longer follow up period is also necessary for understanding the progression and severity of trismus over time. Prospective cohort study with a longer follow up time is suggested.

\section{Conclusion $: \therefore$.}

The results of this study suggest that patients with H\&NC, without physical therapeutic intervention, present restriction of mandibular movements during radiotherapy indicating that this physical complication should be evaluated during the course of RT, mainly if the patients present a reduced functional capacity, have radiation to mouth and oropharynx fields and used of NTF. The variables disease staging, total dose of RT and combined chemotherapy had not represented statistically significant risk factors in relation to the occurrence of mandibular hypomobility.

\section{References : :}

1. Colombo J, Rahal P. Alterações genéticas em câncer de cabeça e pescoço. Rev Bras Cancerol. 2009;55(2):165-74.

2. Instituto Nacional de Câncer (Brasil). Estimativa 2010: Incidência de câncer no Brasil. Acesso em 27 set. 2011. Disponível em: <http://www.inca.gov.br/estimativa/2010/index.asp>.

3. Alvarenga LM, Ruiz MT, Pavarino-Bertelli EC, Ruback MJC, Maniglia JV, Goloni-Bertollo EM. Avaliação epidemiológica de pacientes com câncer de cabeça e pescoço em um hospital universitário do noroeste do estado de São Paulo. Rev Bras Otorrinolaringol. 2008;74(1):68-73.

4. Cardoso MFA, Novikoff S, Tresso A, Segreto RA, Cervantes 0. Prevenção e controle das seqüelas bucais em pacientes irradiados por tumores de cabeça e pescoço. Radiol Bras. 2005;38(2):107-15.
5. Louise Kent M, Brennan MT, Noll JL, Fox PC, Burri SH, Hunter JC, et al. Radiation-induced trismus in head and neck cancer patients. Support Care Cancer. 2008;16(3):305-9.

6. Choi S, Myers JN. Molecular pathogenesis of oral squamous cell carcinoma: implications for therapy. J Dent Res. 2008;87(1):14-32.

7. Ridder T. Orofacial physiotherapy after radiotherapy in the head and neck region. Cranio. 1993;11(3):242-4.

8. Caccelli EMN, Rapoport A. Para-efeitos das irradiações nas neoplasias de boca e orofaringe. Rev Bras Cir Cabeça Pescoço. 2008:37(4):198-201

9. Oliveira CSO, Vieira CA, Mota MHM, Salles PV, Salles JMP, Ninno CQMS, et al. Identificação das mudanças na mastigação e deglutição de indivíduos submetidos à glossectomia parcial. Rev Soc Bras Fonoaudiol. 2008;13(4):338-43 
10. Shenoy VK, Shenoy KK, Rodrigues S, Shetty P. Management of oral health in patients irradiated for head and neck cancer: A review. Kathmandu Univ Med J (KUMJ). 2007;5(1):117-20.

11. Jham BC, Freire ARS. Complicações bucais da radioterapia em cabeça e pescoço. Rev Bras Otorrinolaringol. 2006;72(5):704-8.

12. Rocha RCA, Lehn CN, Oliveira JX, Marcucci M. Incidência de osteorradionecrose em pacientes com câncer de boca tratados com radioterapia exclusiva ou em associação com cirurgia. Rev Bras Cir Cabeça Pescoço. 2008;37(2):91-4

13. Salazar M, Victorino FR, Paranhos LR, Ricci ID, Gaeti WP, Caçador NP. Efeitos e tratamento da radioterapia de cabeça e pescoço de interesse ao cirurgião dentista: revisão da literatura. Rev Odonto (São Bernardo do Campo). 2008;16(31):62-8

14. Vier FV, Cherubini K, Figueiredo MAZ, Yurgel LS. Manejo da osteorradionecrose em pacientes submetidos à radioterapia de cabeça e pescoço. Rev Odonto Ciênc. 2005;20(47):23-8.

15. Sassi LM, Machado RA. Protocolo pré-radioterapia de cabeça e pescoço. Rev Bras Cir Cabeça Pescoço. 2009;38(3):208-10.

16. Lazarus $\mathrm{C}$. Tongue strength and exercise in healthy individuals and in head and neck cancer patients. Semin Speech Lang. 2006;27(4):260-7.

17. Teguh DN, Levendag PC, Voet P, van der Est H, Noever I, de Kruijf W, et al. Trismus in patientes with oropharyngeal cancer: relationship with dose in structures of mastication apparatus. Head Neck. 2008;30(5):622-30.

18. Johnson J, van As-Brooks CJ, Fagerberg Mohlin B, Finizia C. Trismus in head and neck cancer patients in Sweden: incidence and risk factors. Med Sci Monit. 2010;16(6):CR278-82.

19. Dhanrajani PJ, Jonaidel O. Trismus: aetiology, differential diagnosis and treatment. Dent Update. 2002;29(2):88-94

20. Angelo AR, Medeiros AC, Biasi RCCG. Qualidade de vida em pacientes com câncer na região de cabeça e pescoço. Rev Odontol UNESP (Online). 2010;39(1):1-7.

21. Ichimura K, Tanaka T. Trismus in patients with malignant tumours in the head and neck. $J$ Laryngol Otol. 1993;107(11):1017-20.

22. Goldstein M, Maxymiw WG, Cummings BJ, Wood RE. The effects of antitumor irradiation on mandibular opening and mobility: a prospective study of 58 patients. Oral Surg Oral Med Oral Pathol Oral Radiol Endod. 1999;88(3):365-73

23. Dijkstra PU, Kalk WW, Roodenburg JL. Trismus in head and neck oncology: a systematic review. Oral Oncol. 2004;40(9):879-89.

24. Vissink A, Burlage FR, Spijkervet FK, Jansma J, Coppes RP. Prevention and treatment of the consequences of head and neck radiotherapy. Crit Rev Oral Biol Med. 2003;14(3):213-25.

25. Oppenheimer R, Finkel R, Brennan A. Treatment of radiation-induced fibrosis of the face with manual compression therapy. Ear Nose Throat J. 2004;83(7):478-80.

26. Grandi G, Silva ML, Streit C, Wagner JC. A mobilization regimen to prevent mandibular hypomobility in irradiated patients: an analysis and comparison of two techniques. Med Oral Patol Oral Cir Bucal. 2007;12(2):E105-9.

27. Schag C, Heinrich RL, Ganz PA. Karnofsky performance status revisited: reliability, validity and guidelines. J Clin Oncol. 1984;2(3):187-93

28. Unamuco MRDL, Marchini JS. Sonda nasogástrica/nasoentérica: cuidados na instalação, na administração da dieta e prevenção de complicações. Medicina (Ribeirão Preto). 2002;35(1): 95-101.

29. Chasen MR, Bhargava R. A descriptive review of the factors contributing to nutritional compromise in patients with head and neck cancer. Support Care Cancer. 2009;17(11):1345-51.

30. União Internacional Contra o Câncer. TNM Classificação de Tumores Malignos. $6^{\text {a }}$ Ed. Rio de Janeiro: INCA; 2004

31. Research Diagnostic Criteria for Temporomandibular Disorders Consortium. Acesso em 26 set 2010; Disponível em: <http://www.rdc-tmdinternational.org>.

32. Dedivitis RA, França CM, Mafra ACB, Guimarães FT, Guimarães AV. Características clínicoepidemiológicas no carcinoma espinocelular de boca e orofaringe. Rev Bras Otorrinolaringol. 2004;70(1):35-40
33. Cintra AB, Vale LP, Feher 0 , Nishimoto IN, Kowalski LP, Angelis EC. Deglutição após quimioterapia e radioterapia simultânea para carcinomas de laringe e hipofaringe. Rev Assoc Med Bras (1992) 2005;51(2):93-9

34. Döbrossy L. Epidemiology of head and neck cancer: magnitude of the problem. Cancer Metastasis Rev. 2005;24(1):9-17

35. Lothaire P, de Azambuja E, Dequanter D, Lalami Y, Sotiriou C, Andry G, et al. Molecular markers of head and neck squamous cell carcinoma: promising signs in need of prospective evaluation. Head Neck. 2006;28(3):256-69

36. Thomas GR, Nadiminti H, Regalado J. Molecular predictors of clinical outcome in patients with head and neck squamous cell carcinoma. Int J Exp Pathol. 2005;86(6):347-63.

37. Magrin J, Kowalski LP. Complicações das cirurgias por câncer de boca e de orofaringe. Rev Bras Cir Cabeça Pescoço. 2003;31(2):45-8.

38. Dijkstra PU, Huisman PM, Roodenburg JL. Criteria for trismus in head and neck oncology. Int J Oral Maxillofac Surg. 2006;35(4):337-42.

39. Ribas PF, Savioli C, André M, Dias RB. Avaliação da abertura bucal em pacientes submetidos à radioterapia de cabeça e pescoço. Odonto (São Bernardo do Campo). 2011;19(38):99-104

40. Al-Ani MZ, Gray RJ. Evaluation of three devices used for measuring mouth opening. Dent Update. 2004;31(6):346-8, 350

41. Vissink A, Jansma J, Spijkervet FK, Burlage FR, Coppes RP. Oral sequelae of head and neck radiotherapy. Crit Rev Oral Biol Med. 2003;14(3):199-212.

42. Dijkstra PU, Sterken MW, Pater R, Spijkervet FK, Roodenburg JL. Exercise therapy for trismus in head and neck cancer. Oral Oncol. 2007;43(4):389-94.

43. Wollin M, Gilbert HA, Kagan AR. Unequal weighting of given doses in opposed fields in treatment of cancer of the tonsillar region using 60Co, 4-, 8-, 15-, 24-Mvp photons. Med Phys. 1976;3(2):113-6.

44. Araújo SSC, Padilha DMP, Baldisserotto J. Avaliação da condição de saúde bucal e da qualidade de vida de pacientes com câncer de cabeça e pescoço atendidos em um hospital público de Porto Alegre. Rev Bras Cancerol. 2009;55(2):129-38

45. Minarrini BAS, Diniz TS, Mazzini APB, Verdeiro ACH, Vital FMR, Sleutjes LF. Déficit funcional pósradioterapia. Proceedings of the III Congresso Internacional de Oncologia e Cirurgia Onco Reparadora do CBOnco; 2005 Oct 28-29; Muriaé - MG. Muriaé: Revista Científica da FAMINAS. 2006;2:14.

46. Rocabado M. A articulação temporomandibular. In: Rocabado M. Cabeça e pescoço: tratamento articular. Seção 2. São Paulo: Oclusivo; 1999. p. 15-47.

47. Thomas GR, Nadiminti H, Regalado J. Molecular predictors of clinical outcome in patients with head and neck squamous cell carcinoma. Int J Exp Pathol. 2005;86(6):347-63

48. Duval PA, Vargas BL, Fripp JC, Arrieira ICO, Lazzeri B, Destri K, et al. Caquexia em pacientes oncológicos internados em um programa de internação domiciliar interdisciplinar. Rev Bras Cancerol. 2010;56(2):207-12.

49. Melo ILP, Dantas MAM, Silva LC, Lima VT, Lima SCV, Sena KCM. Avaliação nutrional de pacientes cirúrgicos com câncer de cabeça e pescoço sob a terapia nutricional enteral. Rev Bras Nutr Clin. 2006;21(1):6-11.

50. Bensadoun RJ, Riesenbeck D, Lockhart PB, Elting LS, Spijkervet FK, Brennan MT, et al. A systematic review of trismus induced by cancer therapies in head and neck cancer patients. Support Care Cancer. 2010;18(8):1033-8.

51. Steelman R, Sokol J. Quantification of trismus following irradiation of the temporomandibular joint. Mo Dent J. 1986;66(6):21-3.

52. Nguyen TD, Panis X, Froissart D, Legros M, Coninx P, Loirette M. Analysis of late complications after rapid hyperfractionated radiotherapy in advanced head and neck cancers. Int J Radiat Oncol Biol Phys. 1988;14(1):23-5.

53. Stubblefield MD, Manfield L, Riedel ER. A preliminary report on the efficacy of a dynamic jaw opening device (dynasplint trismus system) as part of the multimodal treatment of trismus in patients with head and neck cancer. Arch Phys Med Rehabil. 2010;91(8):1278-82.

54. Tang $Y$, Shen $Q$, Wang $Y$, Lu K, Wang Y, Peng Y. A randomized prospective study of rehabilitation therapy in the treatment of radiation-induced dysphagia and trismus. Strahlenther Onkol. 2011;187(1):39-44 